\title{
Towards lean and green thinking in construction projects at Gaza Strip
}

DOI 10.2478/otmcj-2018-0011

Received January 15, 2018; accepted October 16, 2018

\section{Abstract}

Background and problem: Integrating lean and green principles while implementing construction project has become an important aspect of modern construction. Lean construction and green building are used to maximize the economic benefits, address quality, reduce waste and minimize the negative environmental impacts in construction.

Aims: The objectives of this paper were to measure the degree of knowledge of lean and green approaches in construction industry in Gaza Strip and to identify the most important benefits from application of lean and green in construction.

Methodology: Literature review and questionnaire survey were used in this study. A total of 155 copies of the questionnaire were distributed randomly to owners, consultants and contractors in the Gaza Strip, and 119 copies of the questionnaire were received.

Results: The results revealed that the awareness level of lean and green construction by owners, consultants and contractors in the construction industry in Gaza Strip is moderate. There are very important benefits of applying lean and green construction such as "reduce non-useful work that does not add value to work", "reduce the environmental impact of the construction process" and "saving the money needed to complete the project".

Conclusions: It was concluded that integrating both concepts on projects showed that lean leads to green but not necessarily vice versa. The fields of lean and green thinking, however, have been developed largely

\footnotetext{
*Corresponding author: Nabil I. El-sawalhi, The Islamic University of Gaza, P.O. Box 108, Gaza, Palestine, Tel.: +972 8283 2000, Fax: +972 8264 4800, E-mail: nsawalhi@iugaza.edu.ps

Bilal Majid Jaber and Abed Al Shukri, The Islamic University of Gaza, Gaza, Palestine
}

independent of each other. There is a big gap in the knowledge and application of the lean construction and the green application.

Keywords: Lean construction, Green building, Lean and green construction, Construction industry, Gaza Strip

\section{Introduction}

The development of the lean construction literature has been significant, and practitioners have shown increasing interest in new methodologies (Herranz Limon 2015). The academic literature is very positive towards lean construction and encourages companies to use lean principles in their work (Jörgensen and Emmitt 2008). Many institutions have adopted the idea of lean construction because of its valuable benefits to the project as a whole. Whereas the most important of these benefits is reduce waste through process improvement to optimize flows, it also works as organized production systems to minimize waste of materials, time, and effort; maximize value of works and improve productivity.

The second important point is green building. Othman et al. (2014) explained that current generations have the right to use the natural resources to achieve their goals and meet their needs. However, using these resources inefficiently compromises the ability of future generations to meet their own needs. Therefore, there should be a trade-off between high-comfort modern buildings and resource consumption and environment degradation. We note that many institutions are aware of the powerful and beneficial effects of integrating the lean philosophy with green building in the construction industry. So, some of the innovative companies have been concerned with changing their work practices in line with this awareness. Construction industry is encouraged to adopt lean principles as a powerful approach to increase its efficiency, effectiveness and eliminating waste (Othman et al. 2014). Furthermore, green building is adopted to enhance 
health, to improve building performance, useful life and reuse of materials, and basically to minimize impact on environment.

In Gaza Strip, the construction sector faces some serious challenges. Gaza Strip established thousands of buildings in recent decades, without taking into consideration green building specifications and lean project management approach. Most of the construction projects in Gaza Strip are characterized by inefficiencies, large variability and low performance and thus wasting time, money and other resources (Al-Maghony 2006).

These inherent problems need to be solved in order to bring an overall change and improvement in the current scenario of the construction industries. The need for the change can only be resolved by adoption of lean and green construction in construction industry of Gaza Strip.

This paper would measure the degree of knowledge of lean and green approaches so that the construction industry can be improved, whereas both approaches are seeking to reduce waste and environmental damage and improve the construction industry. The most important benefits of application of lean and green in construction are clarified.

\section{Lean construction}

Koskela (2000) stated that the construction should be seen as a combination of conversion and flow processes for waste removal. Lean construction is to a great extent an adaptation and implementation of the Japanese manufacturing principles, and the concept is implemented in the construction process (Bertelsen 2004). Implementing lean production philosophy to construction presents challenges due to the significant differences in the physical characteristics of the end product of manufacturing and construction. Yet, it meant to be a step forward as it presents a lot of potentials to improve the industry (Salem et al. 2006).

Carneiro et al. (2012) showed that lean construction is associated with the implementation and adaption of concepts and principles of the Toyota Production System in civil engineering management. Its main objective is to reduce waste through process improvement to optimize flows and to increase product quality. Lean construction is the process that involves site staff and planning to workers not waiting for work and work not waiting for workers, which is affected by social disturbances. Lean construction defines a management process based on a production approach to project delivery, which is particularly useful when there is complexity and uncertainty (Koskela et al. 2002).

There are numerous benefits from implementation of lean tools and techniques. Premkumar and Ranganathan (2012) summarized these benefits as follows: quality performance, fewer defects and rework, fewer machine and process breakdowns, lower levels of inventory, less space required, higher efficiencies, more output per man hour, improved delivery performance, faster development, greater customer satisfaction, improved employee morale and involvement, improved supplier relations and increased business.

\section{Green construction}

Sustainable (green) development is a challenge to meet the growing needs of human and natural resources, industrial products, energy, food, transportation and shelter, and effective waste management while preserving and protecting the quality of the environment and the necessary basis for the lives and the future development of natural resources. This concept recognizes that meeting long-term human needs will be impossible unless we also conserve the earth's natural physical, chemical and biological systems (US Green Building Council 1996).

The construction industry is one of the most important industries that contributes towards the social and economic growth, particularly for developing countries (Hussin et al. 2013).

Buildings and the built environment play a major role in the human influence on the natural environment and quality of life. The benefits of inclusion sustainable design principles in the construction projects can include resources, energy efficiency and sanitary buildings and materials, environmentally sensitive lands and use socially, and transportation efficiency, and enhance the economies and societies (US Green Building Council 1996).

The application of green sustainable construction in the construction of buildings and design could promote both economic growth and environmental health in Gaza Strip. Thus, the key aspects of the green building industry are needed to develop projects in an integrated manner. This requires owners', designers' and constructors' cooperation in sustainable projects (Hyatt 2011).

The construction industry is one of the largest contributors to pollution and waste through its life cycle, and it is linked to about $40 \%$ of the use of resources and energy in the world to build and maintain buildings. More than 30\% 
of the traditional buildings have poor indoor air quality, and we spend about $90 \%$ of our time at home. They can address these issues through the green building approach (Hussin et al. 2013). There could be significant benefits of using green construction. Salama and Hana (2010) summarized studies of some researches and showed benefits of green building such as lower energy costs, lower maintenance costs, healthier environment that reduces absenteeism and attention sustainability considerations of economical, environmental and social impact from design stage throughout the building's life cycle.

Green building can be used to achieve changing the direction of the construction projects towards a healthier environment, improve sustainability development and a cost-effective approach.

\section{Lean and green construction}

Over the last 5 years, an increasing number of researchers are looking to implementation of lean construction practices with green in an attempt to improve performance and efficient productivity in construction projects worldwide. Researchers' studies have reported morbidity results from implementation of this approach.

Lean and green strategies are often seen as compatible initiatives because of their joint focus on waste reduction (Mollenkopf et al. 2010). Pezic (2012) showed that the fundamentals of green and lean can be described as project success: When "the project meets the technical performance specifications and/or mission to be performed, and if there is a high level of satisfaction concerning the project outcome among key people on the project team, and key users or clientele of the project effort”. Also it can be described as Value: Value is what the customer or client is willing to pay for. In order to deliver maximal value, there needs to be a minimization of the nine wastes (defects, over processing, transportation, motion, waiting, inventory, overproduction, underutilization of creativity and environmental waste). Included in the value aspect, the iron triangle needs to be considered. To really deliver value, the project needs to be on time, within budget and within acceptable performance/quality. Finally it can be as Sustainable development: Meeting the needs of a firm's direct and indirect stakeholders (such as shareholders, employees, clients, pressure groups and communities) without compromising the ability to meet the needs of future stakeholders as well.

In times when sustainability is a major concern in public opinions all around the planet, the effectiveness of lean construction in controlling and eliminating wastes has becoming more and more acknowledged (Vieira and Cachadinha 2011). Therefore, the construction industry has a great potential for promoting sustainable development. One of the possible approaches to this promotion is implementing lean construction principles through the introduction of social and environmental values as new targets to achieve, rather than focusing on just accidental benefits of lean construction to the environment (Bae and Kim 2007). Bae and Kim (2007) explained the contribution of lean construction tools to the sustainability of a project. It is important to highlight how the parallel seeking for lean and green wastes can be a catalyst for total waste reduction alongside the implementation of lean and green thinking in operational procedures. One of the priorities of lean construction is the elimination of waste as lean construction tools have evolved to contribute to sustainable construction. Similarly, sustainable construction focuses on the removal of waste from the construction process. Therefore, it could be said that both concepts share the same goal of waste reduction. However, organizations struggle to integrate the concepts (Koranda et al. 2012).

Green construction is viewed by Horman et al. (2004) as a strategy that can emphasize reductions in building energy use, water use, materials employed and pollution. The economic case for sustainability (green) initiatives is made on life cycle cost savings, as most sustainable systems tend to involve a higher initial cost. Galeazzo et al. (2014) investigated in their research that joint implementation of lean and green practices and their interaction might be implemented either sequentially or simultaneously, thereby generating sequential or reciprocal interdependencies, respectively. Furthermore, they found that reciprocal interdependencies are more likely to be associated with the involvement of external suppliers and that the simultaneous adoption of lean and green practices ultimately leads to better operational performance.

In one of the most recent extensive literature review on the relationship between lean and green, $\mathrm{Ng}$ et al. (2015) (cited in Dües et al. 2013) compared the two paradigms and identified their differences and overlapping relationship. They concluded that the commonalities serve as a basis for lean and green implementation. Specifically, their research findings point out that a lean environment acts as a catalyst to enable green implementation and that the integration of lean and green will lead to better performances and results for companies (Ng et al. 2015). 


\section{Methodology}

A comprehensive overview was conducted to identify the major benefits and activities to adopt lean and green construction. Collected data in this phase were refined and investigated by different experts and then used in designing the questionnaire. Before the main survey was launched, a pretesting process was conducted to ensure the clarity and relevance of the questions. For piloting purpose, 30 copies of the questionnaire were distributed conveniently to respondents from the target group. All the copies were collected and analysed. The questionnaire was amended accordingly.

The main population of the questionnaire survey was the 1st (A, B) and 2nd classes of building contractors, consulting engineering companies and engineering offices according to Engineers Syndicate - Gaza Strip (2017) and the public owner agencies consisting of government agencies, ministries, municipalities, international agencies, non-governmental organizations (NGOs) and public project owners. The questionnaire was distributed to 70 contracting companies, 45 consulting offices and 40 public owners. Only 119 valid questionnaires from all categories were returned with a response rate of $76.7 \%$.

SPSS Version 22 for Windows was used for the data analysis. The Relative Importance Index (RII) method was used to determine the ranks of all questionnaire factors. The RII was computed as follows (Sambasivan and Soon 2007):

$$
\mathrm{RII}=\frac{\sum W}{A \times N}
$$

where $W$ is the weighting given to each factor by the respondents (ranging from 1 to 5), $A$ is the highest weight (i.e. 5 in this case) and $N$ is the total number of respondents.
The RII value had a range from 0 to 1 ( 0 not inclusive); the higher the value of RII, the more the impact of the attribute.

\section{Results analysis and discussion}

\subsection{Respondent's profile}

Table 1 illustrates the results of respondent's profile. It shows that $43.7 \%$ (52) respondents are contractors, $27.7 \%$ (33) respondents are owners and $28.6 \%$ (34) respondents are consultants. This indicates the diversity of the groups satisfactorily and is required for the success of this study.

Concerning the respondents experience in the construction works, it can be seen that most contractors participating in this study have a satisfactory experience in construction industry of more than 5 years. This could imply that more accurate responses can be obtained.

Finally, the total value of executed projects during the last 5 years for each institution is represented as follows: $32(26.9 \%)$ of respondents executed projects with cost less than one million dollars and $46(38.7 \%)$ of respondents executed projects with cost ranging from one to five million dollar. On the other hand, 41 (34.5\%) of respondents executed projects of total cost more than five million dollar. This shows that the surveyed institution is of a medium size.

\subsection{Awareness level of lean and green construction}

Table 2 shows that all parties ranked "I think there is a big gap in the knowledge and application of the lean construction of workers in the construction industry in the

Tab. 1: Respondent's profile.

\begin{tabular}{llcc}
\hline Information about respondents & Categories & Frequency & Percentage \\
\hline Type of institution & Owner (public or private sector institution) & 33 & 27.7 \\
& Consultant & 34 & 28.6 \\
& Contractor & 34 & 43.7 \\
Respondent's experience in the construction & Less than 5 years & 42 & 28.6 \\
works (years) & From 5 years to less than 10 years & 25 & 35.3 \\
& From 10 years to less than 20 years & 18 & 21 \\
Total value of executed projects during the & 20 years and over & 32 & 15.1 \\
last 5 years & Less than 1 million USD & 46 & 26.9 \\
& From 1 to 5 million USD & 41 & 38.7 \\
\hline
\end{tabular}


Tab. 2: Degree of knowledge and awareness of lean construction.

\begin{tabular}{|c|c|c|c|c|c|c|c|c|}
\hline \multirow{2}{*}{$\begin{array}{l}\text { Lean construction knowledge and } \\
\text { awareness statement }\end{array}$} & \multicolumn{2}{|c|}{ Owner } & \multicolumn{2}{|c|}{ Consultant } & \multicolumn{2}{|c|}{ Contractor } & \multicolumn{2}{|c|}{ All parties } \\
\hline & RII & Rank & RII & Rank & RII & Rank & RII & Rank \\
\hline $\begin{array}{l}\text { I have a previous knowledge of the } \\
\text { concept of lean construction }\end{array}$ & 66.06 & 6 & 64.71 & 6 & 65.00 & 5 & 65.21 & 6 \\
\hline $\begin{array}{l}\text { Lean construction is one of the modern } \\
\text { construction methods }\end{array}$ & 67.88 & 5 & 74.12 & 5 & 71.54 & 3 & 71.26 & 4 \\
\hline $\begin{array}{l}\text { The lean construction application } \\
\text { reduces the overall cost of the project }\end{array}$ & 71.52 & 3 & 78.82 & 3 & 72.31 & 1 & 73.95 & 3 \\
\hline $\begin{array}{l}\text { I think there is a big gap in the } \\
\text { knowledge and application of the lean } \\
\text { construction of workers in the } \\
\text { construction industry in Gaza Strip }\end{array}$ & 72.73 & 1 & 80.59 & 2 & 71.92 & 2 & 74.62 & 1 \\
\hline $\begin{array}{l}\text { Your institution is interested in } \\
\text { reducing wastes and increasing value } \\
\text { and benefits }\end{array}$ & 70.91 & 4 & 74.71 & 4 & 63.85 & 6 & 68.91 & 5 \\
\hline $\begin{array}{l}\text { Lean construction will be of great } \\
\text { benefit if adopted in the construction } \\
\text { process in Gaza Strip }\end{array}$ & 72.12 & 2 & 82.35 & 1 & 70.77 & 4 & 74.45 & 2 \\
\hline $\begin{array}{l}\text { Overall knowledge and awareness of } \\
\text { lean construction }\end{array}$ & 70.20 & & 75.88 & & 68.97 & & 71.29 & \\
\hline
\end{tabular}

RII, Relative Importance Index.

Gaza Strip" in the first position, and this result especially is in full conformity with the respondent owners with an RII value equal to 72.73 , where owners in this questionnaire were formal owners (NGOs, ministries, etc.) and they often choose high-quality engineers for their work. This result indicated the agreement among all respondents that the lean construction application is marginalized and weak in Gaza Strip and that its knowledge and awareness of construction participants and workers is insufficient.

The second important statement ranked by all parties, especially by respondent owners, and as a first statement by consultants was "Lean construction will be of great benefit if adopted in the construction process in the Gaza Strip” with RII values equal to 72.12 for owners and 82.35 for consultants. This appears to suggest that although this statement might not necessarily qualify as major to reflect awareness level about lean construction in the construction industry, they should be noted as quiet significant in the context of the Gaza owners and consultants' organizations. This result illustrates the extent of effectiveness of awareness of the importance and impacts of the development of lean issues on the firm's performance and productivity. Furthermore, it indicates management awareness of positive effects resulting from the application of tools and techniques of lean construction.

It should be noted that "The lean construction application reduces the overall cost of the project" was given the first rank by contractors with an RII value equal to
72.31. This indicates that contractors' responses agree that lean construction would reduce costs by reducing waste and improving productivity.

According to all parties (owners, consultants and contractors); it was obtained that "I have a previous knowledge of the concept of lean construction" is ranked in the last position. This is a strong indication that respondents do not have prior knowledge of the concept of lean construction, i.e. before reading the terms at the beginning of the questionnaire. In the opinion of the researcher that the reason for this is due to the adoption of traditional methods of construction in Gaza Strip and not develop a plan for development, lack of interest in the education of these concepts adequately and the absence of items that impose the use and learning of these approaches.

\subsection{Awareness level of green construction}

Table 3 shows the results of general awareness and knowledge of the respondents with regard to the green construction, and it also presents the resulting RII and corresponding ranks. All RII values above $60 \%$ are considered as accepted results and are approved as indicators of the respondents' knowledge and awareness about green building.

Table 3 presents that "The green construction application reduces the cost of the building life cycle" is rated 
Tab. 3: Degree of knowledge and awareness of green building.

\begin{tabular}{|c|c|c|c|c|c|c|c|c|}
\hline \multirow{2}{*}{$\begin{array}{l}\text { Green building knowledge and } \\
\text { awareness statement }\end{array}$} & \multicolumn{2}{|c|}{ Owner } & \multicolumn{2}{|c|}{ Consultant } & \multicolumn{2}{|c|}{ Contractor } & \multicolumn{2}{|c|}{ All Parties } \\
\hline & RII & Rank & RII & Rank & RII & Rank & RII & Rank \\
\hline $\begin{array}{l}\text { I have a previous knowledge of the } \\
\text { concept of green building }\end{array}$ & 69.70 & 6 & 67.65 & 5 & 68.46 & 5 & 68.57 & 5 \\
\hline $\begin{array}{l}\text { Green building is one of the modern } \\
\text { construction methods }\end{array}$ & 73.94 & 4 & 74.71 & 3 & 71.92 & 2 & 73.28 & 4 \\
\hline $\begin{array}{l}\text { The green construction application } \\
\text { reduces the cost of the building life cycle }\end{array}$ & 76.36 & 3 & 77.65 & 1 & 73.08 & 1 & 75.29 & 1 \\
\hline $\begin{array}{l}\text { I think there is a big gap in the knowl- } \\
\text { edge and application of the green con- } \\
\text { struction of workers in the construction } \\
\text { industry in Gaza Strip }\end{array}$ & 76.97 & 2 & 74.12 & 4 & 71.54 & 3 & 73.78 & 3 \\
\hline $\begin{array}{l}\text { Your institution seeks to minimize the } \\
\text { negative environmental impacts of the } \\
\text { project }\end{array}$ & 72.73 & 5 & 64.12 & 6 & 62.69 & 6 & 65.88 & 6 \\
\hline $\begin{array}{l}\text { Green construction will be of great } \\
\text { benefit if adopted in the construction } \\
\text { process in Gaza Strip }\end{array}$ & 78.79 & 1 & 75.29 & 2 & 71.51 & 4 & 74.62 & 2 \\
\hline $\begin{array}{l}\text { Overall knowledge and awareness of } \\
\text { green building }\end{array}$ & 74.75 & & 72.25 & & 69.85 & & 71.90 & \\
\hline
\end{tabular}

RII, Relative Importance Index.

as the most important factor by all parties, especially by consultants, and got the highest rank with an RII value equal to 77.65. In addition, this result is in full conformity with contractors (RII $=73.08)$. This similarity of opinions reflects the awareness about this statement, but in case of owners, the proportion of the importance index is lower, which means that consultants and contractors are more aware of these elements and give them greater priority. In general, all parties ranked this statement at the first position with an RII value equal to 75.29 , which indicates the agreement of all parties that organizations adopting green building will have a greater chance of enhancing their long-term competitiveness and reducing the cost of the building life cycle. This perspective can be considered as an incentive for the construction organizations to invest in and implement green building approaches, which include collective efforts towards the efficient and wise utilization of green building technologies in construction.

It is clearly shown that all respondents ranked "Green construction will be of great benefit if adopted in the construction process in Gaza Strip" in the second position. It supports the first result. Since respondents have a sense of the importance of green construction in the construction industry of Gaza Strip, this sense reflects the respondents' awareness of the importance of implementing green construction in Gaza Strip. It should be noted that this result and this item have the same location of the answers of all participants that the lean construction will be of great benefit if adopted in the construction industry in Gaza Strip.

"Your institution seeks to minimize the negative environmental impacts of the project" got the last rank among all statements from all parties with an RII value equal to 65.88. This provides informative evidence that all parties and all construction institutions might need to reconsider their current perceptions about this feature.

\subsection{Benefits of applying lean construction}

Table 4 shows results about questions related to benefits of applying lean construction in improving construction industry of Gaza Strip. "Reduce non-useful work that does not add value to work" was ranked in the first position by all parties with an RII value equal to 80.34 . This result clearly confirms the assertion of Ogunbiyi (2014) who argued that using lean construction tools and techniques in construction leads to eliminate wastes and non-value adding activities.

The results revealed that "Improve cooperation and communication between different specialties and participants" was ranked second by owners in the benefits of applying lean construction. This shows the extent to which owners are aware of the importance of cooperation between all parties involved in the success of any project 
Tab. 4: Analysis results about the benefits of applying lean construction.

\begin{tabular}{|c|c|c|c|c|c|c|c|c|}
\hline \multirow{2}{*}{ Benefits of applying lean construction } & \multicolumn{2}{|c|}{ Owner } & \multicolumn{2}{|c|}{ Consultant } & \multicolumn{2}{|c|}{ Contractor } & \multicolumn{2}{|c|}{ All parties } \\
\hline & RII & Rank & RII & Rank & RII & Rank & RII & Rank \\
\hline $\begin{array}{l}\text { Eliminate unnecessary movements } \\
\text { of workers and equipment on site }\end{array}$ & 80.61 & 4 & 75.88 & 10 & 76.54 & 8 & 77.48 & 8 \\
\hline $\begin{array}{l}\text { Minimize material transfer on site that } \\
\text { does not support construction work }\end{array}$ & 75.76 & 9 & 77.06 & 6 & 74.62 & 11 & 75.63 & 10 \\
\hline $\begin{array}{l}\text { Reduce non-useful work that does not } \\
\text { add value to work }\end{array}$ & 75.15 & 10 & 81.18 & 3 & 83.08 & 1 & 80.34 & 1 \\
\hline $\begin{array}{l}\text { Improve storage (inventory does not } \\
\text { exceed required work) }\end{array}$ & 78.79 & 6 & 77.06 & 7 & 75.77 & 10 & 76.97 & 9 \\
\hline $\begin{array}{l}\text { Reduce redundancy of work (doing } \\
\text { works quickly before need it) }\end{array}$ & 76.97 & 8 & 76.47 & 8 & 80.77 & 2 & 78.49 & 7 \\
\hline $\begin{array}{l}\text { Correct defects continuously } \\
\text { (when the work does not lead to } \\
\text { the specifications) }\end{array}$ & 80.61 & 5 & 81.76 & 1 & 77.31 & 7 & 79.50 & 4 \\
\hline $\begin{array}{l}\text { Improve the exploitation of untapped } \\
\text { workers }\end{array}$ & 84.85 & 1 & 76.47 & 9 & 78.08 & 5 & 79.50 & 5 \\
\hline $\begin{array}{l}\text { Improve cooperation and } \\
\text { communication between different } \\
\text { specialties and participants }\end{array}$ & 82.42 & 2 & 78.82 & 5 & 78.08 & 6 & 79.50 & 6 \\
\hline Improve worker skill level & 77.58 & 7 & 81.76 & 2 & 80.38 & 3 & 80.00 & 3 \\
\hline $\begin{array}{l}\text { Improve the use of materials, } \\
\text { equipment and the area on site }\end{array}$ & 81.82 & 3 & 79.41 & 4 & 79.62 & 4 & 80.17 & 2 \\
\hline $\begin{array}{l}\text { Procedure daily meetings for the } \\
\text { team to solve problems and share } \\
\text { information }\end{array}$ & 73.94 & 11 & 75.29 & 11 & 76.15 & 9 & 75.29 & 11 \\
\hline $\begin{array}{l}\text { Overall benefits of applying lean } \\
\text { construction }\end{array}$ & 78.95 & & 78.29 & & 78.22 & & 78.43 & \\
\hline
\end{tabular}

RII, Relative Importance Index.

and that incompatibility of interests amongst stakeholders caused conflicts and disputes in construction.

Lastly, according to all parties, "Procedure daily meetings for the team to solve problems and share information" is ranked in the last position. This result conforms with the consultants and owners. It can be said that the relationship between lean construction benefits and daily meetings is a weak relation. It could be that meetings among participants in general have a significant positive impact, but if they are done on daily basis, it will incur incremental time and may sometimes lead to some conflicts.

\subsection{Benefits of applying green construction}

As shown in Table 5, the point of view of all parties (owners, consultants and contractors) that "Rational use of water (reduction of water consumption)" was ranked at the first position with an RII value equal to 83.53. This is a strong indication that all respondents feel about the water crisis, which is deteriorating and needs to be treated seriously in Gaza Strip, where all respondents agreed that rational use of water is the greatest benefit of the application of green construction in Gaza Strip.

The second important benefit ranked by owners and contractors as a third important statement by consultants was "Reduce energy consumption in the building and during construction" with an RII value equal to 82.52. This shows the awareness of all parties that Gaza Strip needs to reduce energy consumption in the building and during construction. They also believed that building process consume a high amount of energy in heating, cooling, lighting and construction process. This result clearly confirms the assertion of Rizqa (2016), Chen et al. (2010), Ali and Al Nsairat (2009) and ZainulAbidin and Pasquire (2005) who argued that using green building technologies in construction leads to reduction in energy consumption significantly. On the other hand, this result agreed with Rizqa (2016) who found that this benefit was in the first position in the related category. However, "Reduce energy consumption in the building and during construction" 
Tab. 5: Benefits of applying green construction.

\begin{tabular}{|c|c|c|c|c|c|c|c|c|}
\hline \multirow{2}{*}{$\begin{array}{l}\text { Benefits of applying green } \\
\text { construction }\end{array}$} & \multicolumn{2}{|c|}{ Owner } & \multicolumn{2}{|c|}{ Consultant } & \multicolumn{2}{|c|}{ Contractor } & \multicolumn{2}{|c|}{ All parties } \\
\hline & RII & Rank & RII & Rank & RII & Rank & RII & Rank \\
\hline $\begin{array}{l}\text { Rational use of water (reduction in } \\
\text { water consumption) }\end{array}$ & 80.00 & 7 & 87.65 & 1 & 83.08 & 1 & 83.53 & 1 \\
\hline $\begin{array}{l}\text { Reduce the environmental impact of } \\
\text { the construction process }\end{array}$ & 80.61 & 5 & 80.00 & 4 & 81.15 & 4 & 80.67 & 3 \\
\hline $\begin{array}{l}\text { Reduction in operational costs (mainte- } \\
\text { nance costs) }\end{array}$ & 76.97 & 13 & 78.80 & 7 & 77.69 & 13 & 77.82 & 12 \\
\hline $\begin{array}{l}\text { Improve marketing for engineers and } \\
\text { contractors who have the skills to } \\
\text { implement green construction }\end{array}$ & 81.21 & 4 & 76.45 & 10 & 78.46 & 10 & 78.66 & 10 \\
\hline $\begin{array}{l}\text { Reduce the total cost of the building } \\
\text { life cycle }\end{array}$ & 78.79 & 10 & 74.09 & 14 & 78.06 & 12 & 77.14 & 14 \\
\hline $\begin{array}{l}\text { Provide comfort for residents of the } \\
\text { building and maintain their health }\end{array}$ & 81.82 & 3 & 74.12 & 13 & 78.08 & 11 & 77.98 & 11 \\
\hline $\begin{array}{l}\text { Improve the quality of internal environ- } \\
\text { ment of the buildings (through sound } \\
\text { and heat insulation techniques) }\end{array}$ & 79.39 & 8 & 75.29 & 11 & 80.77 & 6 & 78.82 & 9 \\
\hline $\begin{array}{l}\text { Promote the idea of achieving sustain- } \\
\text { able development through sustainable } \\
\text { construction }\end{array}$ & 78.74 & 11 & 76.47 & 9 & 81.54 & 3 & 79.33 & 7 \\
\hline $\begin{array}{l}\text { Take care of the companies that follow } \\
\text { lean and green construction in their } \\
\text { projects }\end{array}$ & 75.15 & 14 & 75.27 & 12 & 81.11 & 5 & 77.82 & 13 \\
\hline $\begin{array}{l}\text { Maintaining the environmental } \\
\text { statuses in Gaza Strip }\end{array}$ & 80.57 & 6 & 79.96 & 5 & 77.62 & 14 & 79.16 & 8 \\
\hline $\begin{array}{l}\text { Reduce the negative environmental } \\
\text { impacts of the construction process }\end{array}$ & 78.68 & 12 & 82.94 & 2 & 79.23 & 9 & 80.17 & 5 \\
\hline $\begin{array}{l}\text { Reduce energy consumption in the } \\
\text { building and during construction }\end{array}$ & 83.64 & 2 & 80.59 & 3 & 83.06 & 2 & 82.52 & 2 \\
\hline Reduce solid waste & 79.39 & 9 & 78.82 & 6 & 79.62 & 8 & 79.33 & 6 \\
\hline $\begin{array}{l}\text { Improve the selection of building } \\
\text { components to commensurate with } \\
\text { quality and cost }\end{array}$ & 84.85 & 1 & 77.06 & 8 & 80.00 & 7 & 80.50 & 4 \\
\hline $\begin{array}{l}\text { Overall benefits of applying green } \\
\text { construction }\end{array}$ & 79.98 & & 78.38 & & 79.96 & & 79.52 & \\
\hline
\end{tabular}

RII, Relative Importance Index.

is ranked at the first position. It is worth noting that this result disagreed with that of Huda et al. (2013) where it was ranked 17 out of a total of 31 criteria. They explained in their study the reason for the decline that Serbia (the place of study) has a poor awareness on the issue of energy consumption. Thus, we can explain this difference between the results because of the different nature of the country and its culture and education.

"Maintaining the environmental statuses in Gaza Strip" was ranked at the fourteenth position by contractors with an RII value equal to 77.62, which means the last rank in the responses of contractors. This result indicated that contractors have low awareness of the importance of green building and its positive impact on the environment of Gaza Strip, and the researchers explained that contractors' interest in financial matters relates to the completion of the project at the lowest cost. This finding is inconsistent with that of Abidin and Powmya (2014), Issa and Al Abbar (2015) and Andrade and Bragança (2011), which was highly ranked in their studies.

From contractor's point of view, "Promote the idea of achieving sustainable development through sustainable construction" was ranked at the third position with an RII value equal to 81.54 and at the seventh position from fourteenth position by all parties with an RII value equal to 79.33. This result shows a relative awareness that green building will enhance the idea of caring for the environment by meeting the needs of the present society in Gaza Strip without compromising the needs of the future society. 
Finally, according to all parties, it was obtained that "Reduce the total cost of the building life cycle" is ranked at the last position with an RII value equal to 77.14. This result revealed that the respondents have lack of awareness that green building has great importance where it reduces the total cost of the building life cycle by saving energy, insulation, etc. It is worth noting that this result disagrees with that of Shi et al. (2013).

\subsection{Benefits of the integration of lean construction and green building}

According to all responses presented in Table 6, "Integrating the two methods leads to saving the money needed to complete the project" was the most important benefit as it has the first rank among all benefits with an RII value equal to 85.38. Ogunbiyi (2014) (cited

Tab. 6: Benefits of the integration of lean construction and green construction.

\begin{tabular}{|c|c|c|c|c|c|c|c|c|}
\hline \multirow{2}{*}{$\begin{array}{l}\text { Benefits of the integration of lean } \\
\text { construction and green construction }\end{array}$} & \multicolumn{2}{|c|}{ Owner } & \multicolumn{2}{|c|}{ Consultant } & \multicolumn{2}{|c|}{ Contractor } & \multicolumn{2}{|c|}{ All parties } \\
\hline & RII & Rank & RII & Rank & RII & Rank & RII & Rank \\
\hline $\begin{array}{l}\text { Integrating the two methods leads to } \\
\text { saving the money needed to complete } \\
\text { the project }\end{array}$ & 84.24 & 1 & 80.00 & 3 & 89.62 & 1 & 85.38 & 1 \\
\hline $\begin{array}{l}\text { Integrating the two methods will save } \\
\text { time to complete the project }\end{array}$ & 80.61 & 3 & 75.88 & 6 & 82.31 & 2 & 80.00 & 3 \\
\hline $\begin{array}{l}\text { Integrating the two methods will pre- } \\
\text { serve the environment in Gaza Strip }\end{array}$ & 79.39 & 8 & 81.76 & 1 & 75.38 & 15 & 78.32 & 6 \\
\hline $\begin{array}{l}\text { Integrating the two methods will } \\
\text { enhance the safety of the site }\end{array}$ & 80.00 & 5 & 78.82 & 4 & 78.08 & 8 & 78.82 & 4 \\
\hline $\begin{array}{l}\text { Accreditation the two methods leads } \\
\text { to excellent services from other } \\
\text { institutions }\end{array}$ & 75.15 & 14 & 75.29 & 9 & 77.31 & 11 & 76.13 & 13 \\
\hline $\begin{array}{l}\text { Lean construction will lead to green } \\
\text { sustainability }\end{array}$ & 78.79 & 9 & 77.65 & 5 & 78.85 & 5 & 78.49 & 5 \\
\hline Both lead to eliminate the waste & 79.98 & 7 & 80.59 & 2 & 81.15 & 3 & 80.67 & 2 \\
\hline $\begin{array}{l}\text { Integration will increase the profit ratio } \\
\text { of the executing institution }\end{array}$ & 78.18 & 10 & 72.94 & 16 & 78.46 & 7 & 76.81 & 10 \\
\hline $\begin{array}{l}\text { Integrating the two methods leads to } \\
\text { satisfaction of the owners because } \\
\text { they obtain the best outputs }\end{array}$ & 77.58 & 12 & 73.53 & 15 & 76.54 & 12 & 75.97 & 14 \\
\hline $\begin{array}{l}\text { Integrating the two methods improves } \\
\text { the construction process in all its } \\
\text { stages }\end{array}$ & 80.60 & 4 & 74.12 & 12 & 79.23 & 4 & 78.15 & 7 \\
\hline $\begin{array}{l}\text { Improved productivity and regularity } \\
\text { of work }\end{array}$ & 76.97 & 13 & 74.71 & 10 & 76.15 & 14 & 75.95 & 15 \\
\hline $\begin{array}{l}\text { Integrating the two methods leads } \\
\text { to the solution of problems facing } \\
\text { construction projects }\end{array}$ & 74.45 & 16 & 73.43 & 14 & 72.31 & 16 & 73.28 & 16 \\
\hline $\begin{array}{l}\text { Integrating the two methods will } \\
\text { result in a good working environment } \\
\text { between all project participants }\end{array}$ & 81.21 & 2 & 74.71 & 11 & 77.69 & 10 & 77.82 & 8 \\
\hline $\begin{array}{l}\text { Integrating the two methods leads to } \\
\text { effective planning }\end{array}$ & 74.55 & 15 & 75.82 & 8 & 78.05 & 9 & 76.47 & 12 \\
\hline $\begin{array}{l}\text { Integrating the two methods leads } \\
\text { to the adoption of a successful new } \\
\text { culture in Gaza Strip }\end{array}$ & 77.58 & 11 & 75.86 & 7 & 76.54 & 13 & 76.64 & 11 \\
\hline $\begin{array}{l}\text { Integrating the two methods enhances } \\
\text { the culture of continuous improvement } \\
\text { of institutions }\end{array}$ & 80.00 & 6 & 74.08 & 13 & 78.85 & 6 & 77.82 & 9 \\
\hline $\begin{array}{l}\text { Overall benefits of the integration } \\
\text { of lean construction and green } \\
\text { construction }\end{array}$ & 78.70 & & 76.18 & & 78.53 & & 77.90 & \\
\hline
\end{tabular}

RII, Relative Importance Index. 
in Baiden et al. 2006) explained that integration in construction can be described as the introduction of working practices, methods and behaviours that creates a culture of efficient and effective collaboration by individuals and organizations. Therefore, there is a general agreement that the merger of the two approaches will benefit the overall project and thus reduce the cost necessary to complete the project. Consequently, linkage between lean and green will lead to waste reduction, environmental management, value maximization, health and safety improvement, performance maximization, design optimization, quality improvement, resource management, energy minimization, elimination of unnecessary process, continuous improvement and cost reduction. Lean and green share the same goal of waste elimination and reduce the cost but with different approaches.

According to all parties, it was obtained that "Both lead to eliminate the waste" is ranked as the second important factor with an RII value equal to 80.67. Ogunbiyi et al. (2014) show that waste reduction is ranked as a first position. This agreement in results is a strong indication that similarity of opinions reflects the importance of this benefit.

It is noted that "Integrating the two methods will preserve the environment in Gaza Strip" is ranked at the first position by consultants with an RII value equal to 81.76. This result denotes the good view and awareness that the construction projects in Gaza Strip have a lack of attention to environmental conditions, which must be improved by integrating lean construction with green building in construction work. In addition, the result showed that lean and green will preserve the environment in Gaza Strip and reduce the negative environmental impacts of the construction. Integrating lean and green should be used for to meet our need in the field of construction and the environment. The researcher believes that integration of lean and green will be mandatory in the future.

According to all responses, the findings also showed that "Improved productivity and regularity of work" benefit statement with an RII value equal to 75.95 is ranked in the penultimate position in the overall benefits. It should be noted that employee productivity is affected by many factors in the construction industry, but it can be said that the relationship between lean and green construction benefits and employee productivity/satisfaction is a weak relation. Ries et al. (2006) fined in their research on green buildings that the special feature of green materials and methods can increase the skills of labourers; however, it will incur them incremental time.
Finally, it should be noted that the respondents have good awareness regarding the benefits of the integration of lean construction and green construction and that they are convinced that these two methods will lead to the improvement of projects in Gaza Strip, since the RII values range from $76.18 \%$ to $78.70 \%$ and overall RII value is equal to $77.90 \%$.

\section{Conclusion}

The concept of lean and green in construction has been adopted by many organizations with significant benefits achieved. This has been reported by several authors and researchers in the field of lean construction and green building. However, many of these studies investigated the application of lean or green principle on projects and a few investigated the concept of lean and green with a view of integrating both concepts on projects. Consequently, it can be concluded that lean leads to green, but not necessarily vice versa, which is reiterated and confirmed. The fields of lean and green thinking, however, have been developed largely independent of each other.

The major observation that can be drawn is that the awareness level of lean and green construction by owners, consultants and contractors in the construction industry in Gaza strip is moderate. There is a big gap in the knowledge and application of lean construction of workers in the construction industry in the Gaza Strip and that the green construction application reduces the cost of the building life cycle. Most practitioners do not have enough knowledge and have not heard well about lean construction or green building. However, in general, lean and green construction will be of great benefit if adopted in the construction process in Gaza Strip. This indicates the extent of effectiveness of awareness of the importance and impacts of the lean and green issues development on the institution performance.

These results ensure the important role of implementation of lean and green construction. Both seek to reduce waste and environmental damage and completely improve the construction industry as a whole.

- This research contributes to show the advantages of applying lean and green construction to Gaza Strip and improving its projects through minimizing the negative environmental impacts and maximizing the economic benefits. The research contribution is as follows:This research contributes to increase 
knowledge and awareness of the concept and application of lean and green construction in Gaza Strip where it can be used in the field of education, in courses and training to promote knowledge and awareness.

- Delivering new and distinctive results by presenting the most important benefits of this approach in Gaza Strip, in addition to the awareness of the participants and workers in the construction industry.

- This research helps decision makers in Gaza Strip to identify the future of lean and green construction adoption.

\section{References}

Abidin, N. Z., \& Powmya, A. (2014). Perceptions on motivating factors and future prospects of green construction in Oman. Journal of Sustainable Development, 7(5), p. 231.

Ali, H. H., \& Al Nsairat, S. F. (2009). Developing a green building assessment tool for developing countries - Case of Jordan. Building and Environment, 44(5), pp. 1053-1064.

Al-Maghony, S. S. (2006). Managing and Minimizing Construction Waste in Gaza Strip. Islamic University of Gaza, Palestine.

Andrade, J. B., \& Bragança, L. (2011). Analysis of the impacts of economic and social indicators to sustainability assessment. In: International Conference Sustainability of Constructions Towards a Better Built Environment. Faculty for the Built Environment, University of Malta, Msida, pp. 163-168.

Bae, J.-W., \& Kim, Y.-W. (2007). Sustainable value on construction project and application of lean construction methods. In: Lean Construction: A New Paradigm for Managing Capital Projects - 15th IGLC Conference, July, pp. 312-321. doi: 10.3992/jgb.3.1.156.

Baiden, B. K., Price, A. D. F., \& Dainty, A. R. J. (2006). The extent of team integration within construction projects. International Journal of Project Management, 24, pp. 13-23.

Bertelsen, S. (2004). Lean Construction: Where are we and how to proceed? Lean Construction Journal, 1(October), pp. 46-69. Available at http://www.leanconstructionjournal.org/, Accessed on 3th June 2016.

Carneiro, S., Campos, I., De Oliveira, D., \& Neto, J. (2012). Lean and green: a relationship matrix. In: Proceeding of 20th Annual Conference of IGLC, San Diego, USA, 18-20 July 2012.

Chen, Y., Okudan, G. E., \& Riley, D. R. (2010). Sustainable performance criteria for construction method selection in concrete buildings. Automation in Construction, 19(2), pp. 235-244.

Dües, C. M., Tan, K. H., \& Lim, M. (2013). Green as the new lean: how to use lean practices as a catalyst to greening your supply chain. Journal of Cleaner Production, 40, pp. 93-100.

Galeazzo, A., Furlan, A., \& Vinelli, A. (2014). Lean and green in action: Interdependencies and performance of pollution prevention projects. Journal of Cleaner Production, 85, pp. 191-200.
Gaza Strip. (2017). Engineers Syndicate. List of Engineering Offices. Available at www.enggaza.ps.

Herranz Limon, D. (2015). Measuring lean construction A performance measurement model supporting the implementation of lean practices in the Norwegian construction industry. Master's thesis, NTNU.

Horman, M. J., Riley, D. R., Pulaski, M. H., \& Leyenberger, C. (2004). Lean and green: Integrating sustainability and lean construction. In: CIB World Building Congress, 2-7 May, Toronto. International Council for Research and Innovation in Building and Construction (CIB), Rotterdam, The Netherlands, pp. 2-7.

Huda, M., Rini, T. S., Paing, J., \& Purwito, A. (2013). Analysis of important factors evaluation criteria for green building. The International Journal of Engineering and Science (IJES), 2, pp. 41-47.

Hussin, J. M., Rahman, I. A., \& Memon, A. H. (2013). The way forward in sustainable construction: Issues and challenges. International Journal of Advances in Applied Sciences, 2(1), pp. 15-24. doi: 10.11591/ijaas.v2i1.1321.

Hyatt, B. (2011). A case study in integrating lean, green, BIM into an undergraduate construction management scheduling course. In: Proceedings of 47th ASC Annual International Conference, 2007. Available at http://ascpro0.ascweb.org/archives/ cd/2011/paper/CEUE304002011.pdf.

Issa, N. S. C., \& Al Abbar, S. D. (2015). Sustainability in the Middle East: Achievements and challenges. International Journal of Sustainable Building Technology and Urban Development, 6(1), pp. 34-38.

Jörgensen, B., \& Emmitt, S. (2008). Lost in transition: the transfer of lean manufacturing to construction. Engineering, Construction and Architectural Management, 15(4), pp. 383-398.

Koranda, C., Chong, W. K., Kim, C., Chou, J. S., \& Kim, C. (2012). An investigation of the applicability of sustainability and lean concepts to small construction projects. KSCE Journal of Civil Engineering, 16(5), pp. 699-707.

Koskela, L. (2000). An Exploration towards A Production Theory and its Application to Construction. VTT Technical Research Centre of Finland.

Koskela, L., Howell, G., Ballard, G., \& Tommelein, I. (2002). The foundations of lean construction. In: Best, R., \& de Valence, G. (eds.), Design and Construction: Building in Value. Butterworth-Heinemann, Oxford, UK, pp. 211-226.

Mollenkopf, D., Stolze, H., Tate, W. L., \& Ueltschy, M. (2010). Green, lean, and global supply chains. International Journal of Physical Distribution \& Logistics Management, 40(1/2), pp. 14-41.

$\mathrm{Ng}$, R., Low, J. S. C., \& Song, B. (2015). Integrating and implementing lean and green practices based on proposition of Carbon-Value Efficiency metric. Journal of Cleaner Production, 95, pp. 242-255.

Ogunbiyi, O. E. (2014). Implementation of the lean approach in sustainable construction: a conceptual framework. Doctoral dissertation, University of Central Lancashire.

Ogunbiyi, O., Goulding, J. S., \& Oladapo, A. (2014). An empirical study of the impact of lean construction techniques on sustainable construction in the UK. Construction Innovation, 14(1), pp. 88-107.

Othman, A. A. E., Ghaly, M. A., \& ZainulAbidin, N. (2014). Lean principles: An innovative approach for achieving sustainability in the Egyptian construction industry. Organization, 
Technology and Management in Construction: An International Journal, 6(1), pp. 917-932. doi: 10.5592/otmcj.2014.1.2.

Pezic, A. (2012). Green lean; How sustainability can be integrated into projects through lean concepts. Unpublished Masters' thesis, Chalmers University of Technology.

Rajuvadan Premkumar, H., \& Vedapatti Ranganathan, H. (2012). Improving supply chain performance through lean and green: $\mathrm{A}$ study at Volvo group in India and Sweden.

Ries, R., Bilec, M. M., Gokhan, N. M., \& Needy, K. L. (2006). The economic benefits of green buildings: a comprehensive case study. The Engineering Economist, 51(3), pp. 259-295.

Rizqa, E. (2016). Promoting green building by investigating sustainability concepts in building projects with regard to economic, environment, social, and technical goals. Master Theses. Palestine, the Islamic University-Gaza.

Salama, M., \& Hana, A. R. (2010). Green buildings and sustainable construction in the United Arab Emirates. In: Egbu, C. (ed.), Proceedings of the 26th Annual ARCOM Conference, 6-8 September 2010, Leeds, UK. Association of Researchers in Construction Management, pp. 1397-1405.
Salem, O., Solomon, J., Genaidy, A., \& Minkarah, I. (2006). Lean construction: From theory to implementation. Journal of Management in Engineering, 22(4), pp. 168-175.

Sambasivan, M., \& Soon, Y. W. (2007). Causes and effects of delays in Malaysian construction industry. International Journal of Project Management, 25(5), pp. 517-526.

Shi, Q., Zuo, J., Huang, R., Huang, J., \& Pullen, S. (2013). Identifying the critical factors for green construction - An empirical study in China. Habitat International, 40, pp. 1-8.

US Green Building Council. (1996). Sustainable Building Technical Manual: Green Building Design, Construction, and Operations. Public Technology, Inc, Washington, DC.

Vieira, A. R., \& Cachadinha, N. (2011). Lean construction and sustainability - Complementary paradigms? A case study. In: Proceeding of the 19th Annual Conference of IGLC, Lima, Peru, pp. 611-621.

ZainulAbidin, N., \& Pasquire, C. L. (2005). Delivering sustainability through value management: Concept and performance overview. Engineering, Construction and Architectural Management, 12(2), pp. 168-180. 